\title{
IMPACT OF THE COVID-19 PANDEMIC ON THE AVAILABILITY OF MEDICAL CARE AMONG ONCOLOGICAL PATIENTS
}

D0I: 10.36740/WLek202107101

\author{
Klaudia Ewa Kościelecka', Aleksandra Joanna Kuć', Daria Małgorzata Kubik', Tomasz Męcik-Kronenberg², \\ Dariusz Ceglarz ${ }^{3}$ \\ 'STUDENT RESEARCH GROUP AT THE CHAIR AND DEPARTMENT OF PATHOMORPHOLOGY, FACULTY OF MEDICAL SCIENCES IN ZABRZE MEDICAL \\ UNIVERSITY OF SILESIA, ZABRZE, POLAND \\ ${ }^{2}$ CHAIR AND DEPARTMENT OF PATHOMORPHOLOGY, FACULTY OF MEDICAL SCIENCES IN ZABRZE, MEDICAL UNIVERSITY OF SILESIA, ZABRZE, POLAND \\ ${ }^{3}$ RADIX, NON-PUBLIC HEALTH CARE FACILITY, ZAWIERCIE, POLAND
}

\begin{abstract}
The aim: Cancer is the second most common cause of death in Polish society. The healthcare system, already overwhelmed in many countries, has been further burdened by the outbreak of the SARS-CoV-2 pandemic. The healthcare system has become inefficient, especially in the oncology care sector. Surgeries, scheduled treatments, and follow-up appointments in some hospitals have been canceled or rescheduled to the "next available date after the end of the pandemic". This research aims to analyze the impact of the COVID-19 pandemic on the availability of medical care among oncological patients and compare them with the results of studies on the effects of postponement of oncology treatment.

Materials and methods: The study included a group of 544 respondents from all over Poland. The research tool was a self-administered survey questionnaire.

Results: $37 \%$, of those undergoing systemic treatment, experienced postponement of their treatment, and in the case of radiotherapy, it was $35 \%$. Visits to the clinical oncologist/ radiotherapist specialist were postponed in $51 \%$ of respondents. Imaging studies were delayed in $41.7 \%$ of respondents.

Conclusions: The course of the COVID-19 pandemic has significantly impacted the health care system and, therefore, also on the availability of medical care among oncological patients. The results signal an emerging problem. These visit shifts may negatively affect the outcome of cancer treatment. The potential risk of COVID-19 infection should be individually balanced against cancer treatment delay in each patient. The ongoing pandemic, therefore, prompts a careful analysis of the effects of deferring cancer therapy.
\end{abstract}

KEY WORDS: oncology, COVID-19 pandemic, cancer patients, participants, health care

Wiad Lek. 2021;74(7):1542-1551

\section{INTRODUCTION}

In December 2019, in Wuhan, central China, a new contagious disease emerged, spanning 218 countries and territories, and lead to the declaration of a pandemic by the World Health Organization. The pathogen responsible for this disease is the beta-coronavirus SARS-CoV-2 [1]. It is similar to SARS-CoV-1 and MERS-CoV, which caused several local epidemics in recent years, in 2002, 2012, and 2015 [2]. Until mid-November 2020, there were 60 million cases and 1.25 million deaths due to COVID-19. However, the death rate is still challenging to determine due to underestimating the actual number of infections [3].

There is a very high variability of clinical symptoms of this infection depending on the patient - from asymptomatic course to respiratory failure leading to the patient's death [2].

The healthcare system, already inefficient in many countries, has been additionally burdened by the SARS-CoV-2 pandemic. The healthcare system has become ineffective, especially in the cancer care sector. Surgeries, planned procedures, and follow-up visits in some hospitals have been and are being canceled or postponed to "the next available date after the end of the pandemic". However, it is still unknown when or if the pandemic ends. Patients have difficult access to medical care or are entirely deprived of it. Such a situation will increase the number of cancer patients not treated or treated with delay, as well as increase the percentage of patients in a highly advanced disease stage. There are over 18 million new diagnoses of cancer worldwide every year, which constitutes a large part of the population [1].

Risk factors and comorbidities such as diabetes, old age, arterial hypertension, or cardiovascular diseases often affect cancer patients. These factors may also be associated with a higher risk of death because of COVID-19. Cancer and cancer treatment are also associated with immunosuppression. Therefore, it seems that oncological patients are a group particularly exposed to the SARS-CoV-2 virus [4-7]. Also, during the MERS pandemic in 2015, it was noticed that the mortality rate among cancer patients was twice as high as in non-cancer patients and amounted to $84 \%$ [8]. Similarly, during the $2009 \mathrm{H} 1 \mathrm{~N} 1$ flu pandemic, the death rate due to infection with this virus in cancer patients was $18.2 \%$ higher. In addition to the direct adverse effects of 
the pandemic, attention should also be paid to limiting the activities of oncology and research centers and suspending clinical trials [9].

In Poland, we observe a significant increase in the number of cases due to infection with the SARS-CoV-2 virus every day. The ever-increasing needs of medical care put into question the possibility of organizational security. There are also many unknowns, such as the dynamics of the increase in the number of infected people requiring hospital treatment, including in intensive care units, or the duration of the pandemic.

Many hospitals cancel planned admissions and suspend the operation of the outpatient clinics, which is related to their transformation into facilities treating only patients suffering from COVID-19. Illness of medical personnel is also a problem, as well as among patients undergoing hospitalization, which often requires a temporary suspension of the ward's work. There are media reports on the closure of departments diagnosing cancer patients and treating oncological patients. Such management may worsen the prognosis or even prevent the chances of a complete recovery for many patients.

Cancer is the second most common cause of death in Polish society. In our country, about 300 people die every day due to oncological disease, and as many as 100,000 people lose their lives every year. Therefore, there is no doubt that it is essential to provide care for newly diagnosed patients and those undergoing treatment. Also, patients with the suspected oncological disease cannot remain without medical care [10]. The COVID-19 pandemic should not result in a complete suspension of admissions for cancer patients. The Polish Cancer Society emphasizes that the correctness of the course as well as the safety of radical treatment are the most important, and modifications of the therapeutic plan may be introduced only when they do not pose a threat to the patient's health and life [11].

About a million people have cancer in Poland, a large group of which being actively treated. Most cases are diagnosed after the age of 65 , so oncological patients are at the same time a population particularly vulnerable to complications and death because of COVID-19, also due to age. The Polish Society of Clinical Oncology believes that "it is necessary to strive to maintain the recommended intensity of treatment on a radical basis. Each time, if it is not possible to continue the systemic radical treatment, the patient must be urgently transferred to another, functioning clinical oncology center in a given voivodeship to continue the treatment" [12].

According to the Recommendations of the National Consultant in oncological radiotherapy, radiotherapy cannot be postponed or withdrawn (if the facility performing this procedure has no epidemic restrictions) because it is a treatment that saves the lives of people suffering from malignant tumors [13]. On the other hand, the Polish Society of Oncological Surgery issued an appeal to hospital authorities to provide patients with diagnostics during the pandemic, as well as treatment with a radical intention.
They also emphasized that maintaining the normal functioning of oncological surgery departments was extremely important, and the effect of treatment depended on the continuity of multidisciplinary therapy of people suffering from oncological diseases [14].

\section{THE AIM}

Many research papers deal with the impact of postponement of treatment caused by the ongoing coronavirus pandemic on the well-being, condition, and survival of patients, paying particular attention to the possible deterioration of prognosis and reduced chances of recovery.

The study aimed to check whether and how the pandemic influenced the availability of medical care among cancer patients and their feelings.

The authors wanted to answer the following questions:

1. Has the COVID-19 pandemic affected the timing of scheduled medical appointments, radiotherapy, systemic treatment, and imaging studies?

2. Do cancer patients comply with the recommendations related to the COVID-19 pandemic in the form of mouth and nose coverage, regular hand washing, and social distancing?

3. Has the coronavirus pandemic increased anxiety levels among cancer patients?

The authors also decided to review scientific papers in search of the effects of postponing various forms of cancer treatment.

\section{MATERIALS AND METHODS}

Five hundred forty-four respondents from all over Poland, of various ages, took part in the study. The proprietary questionnaire prepared for the research was used in accordance with the methodology adopted in this type of study. The questionnaire consisted of two parts. The first part characterized the study group, and the second contained questions about the difficulties in getting access to a medical facility, the availability of oncological treatment (systemic treatment, radiotherapy, imaging studies, visits to a clinical oncology specialist or radiotherapist), and the personal protective equipment used during the COVID-19 pandemic.

The survey was conducted from August 2020 to November 2020 in electronic form. Participation in the survey was completely voluntary. The questionnaire completed independently by the respondents was anonymous. Statistica 13.3 and Microsoft Office Excel 2010 software were used for statistical calculations. The chi-square test of independence was used, and a p-value $<0.05$ was adopted as the significance level. Qualitative and quantitative analysis of the obtained data was the basis for describing the results and achieving the goal of the work.

\section{RESULTS}

The study group was characterized in terms of gender (Fig. 1), age (Fig. 2), place of residence (Fig. 3), voivodeship 

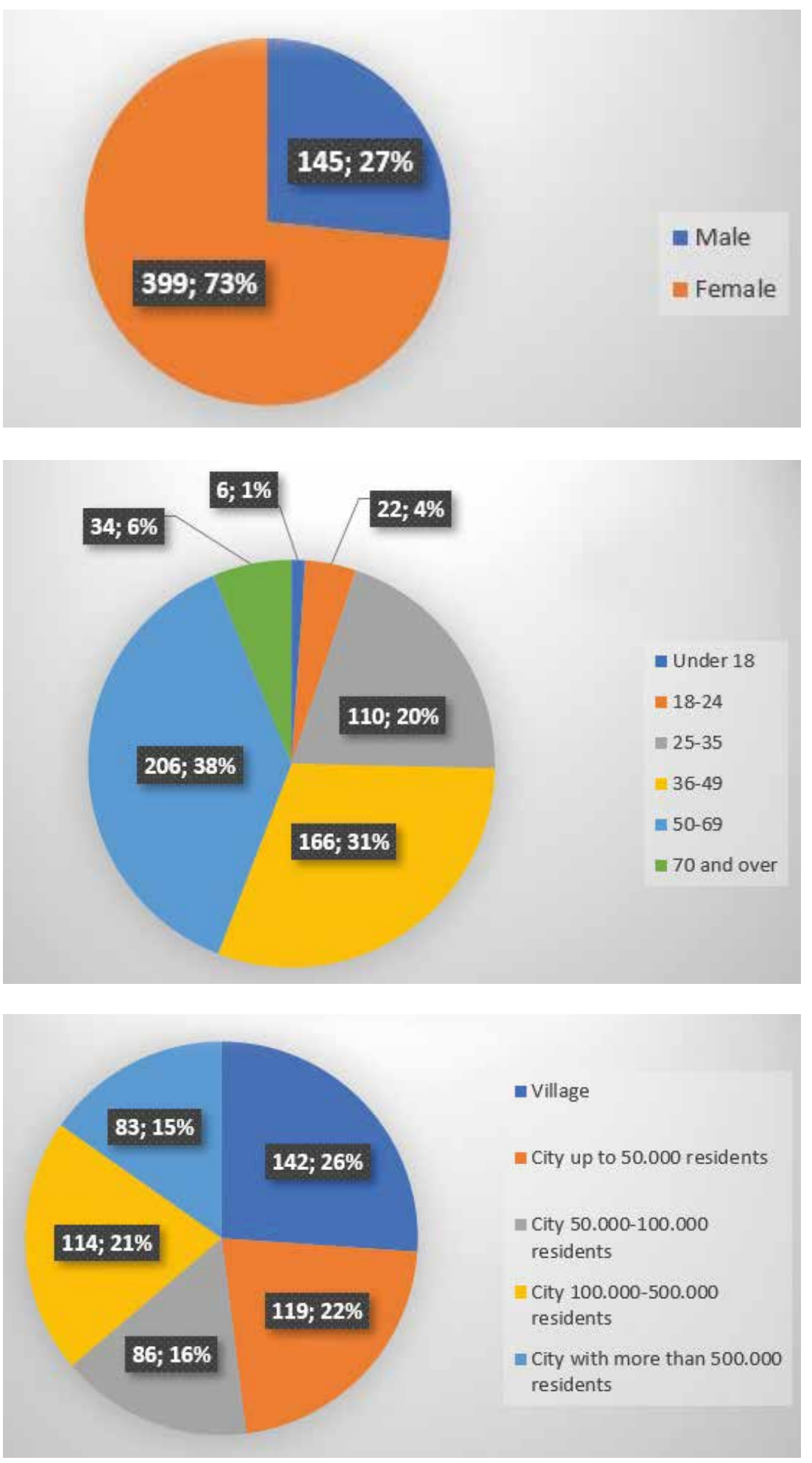

Fig. 1. Gender of the respondents in terms of numbers and percentages.

Fig. 2. Age of respondents in terms of numbers and percentages.

Fig. 3. Place of residence of the respondents in terms of numbers and percentages. where treatment or follow-up after oncological treatment took place (Table 1), and the type of cancer the respondents had (Table 2).

Three hundred eleven of the respondents (57.2\%) were undergoing cancer treatment, and $233(42.8 \%)$ were under observation after cancer treatment. When asked about the difficulties (in connection with the COVID-19 pandemic) in getting access to a medical facility where treatment or follow-up after oncological treatment took place, slightly more than half of the respondents $(\mathrm{n}=282,52 \%)$ indicated that they had no difficulties.

The respondents were asked if the COVID-19 pandemic had an impact on the timing of the planned radiotherapy. $66 \%$ of respondents $(n=358)$ indicated that the question "did not apply to them". Among those receiving radiotherapy $(\mathrm{n}=186,34 \%)$, as many as $65 \%(\mathrm{n}=121)$ maintained that the date of the procedure was not postponed, and $35 \%$ $(n=65)$ announced the postponement of the exposure date. 
Table 1. The number of people undergoing treatment/control in a given voivodeship in terms of numbers and percentages.

\begin{tabular}{|c|c|c|}
\hline The voivodeship where treatment or post-treatment control took place & Number & Percentage[\%] \\
\hline Silesian Voivodeship & 111 & 20 \\
\hline Masovian Voivodeship & 105 & 19 \\
\hline Lesser Poland Voivodeship & 69 & 13 \\
\hline Lower Silesia Voivodeship & 38 & 7 \\
\hline Greater Poland Voivodeship & 37 & 7 \\
\hline Pomeranian Voivodeship & 37 & 7 \\
\hline Kuyavian-Pomeranian Voivodeship & 27 & 5 \\
\hline West Pomeranian Voivodeship & 25 & 5 \\
\hline Lublin Voivodeship & 23 & 4 \\
\hline Subcarpathian Voivodeship & 21 & 4 \\
\hline Lodzkie Voivodeship & 19 & 3 \\
\hline Warmia-Masuria Voivodeship & 10 & 2 \\
\hline Swietokrzyskie Voivodeship & 8 & 1 \\
\hline Podlaskie Voivodeship & 5 & 1 \\
\hline Opole Voivodeship & 5 & 1 \\
\hline Lubusz Voivodeship & 4 & 1 \\
\hline
\end{tabular}

Table 2. The type of cancer that the respondents suffer from in terms of number and percentage.

The next question concerned the impact of the pandemic on the timing of the planned systemic treatment (chemotherapy/biological treatment/hormone therapy).

\section{The cancer type}

epithelial cancer of the head and neck organs

(cancer of the lips, mouth, throat, larynx, nasal cavity, paranasal sinuses, salivary glands)

$$
\begin{gathered}
\text { a tumor of the central nervous system } \\
\text { cancer of the lung, pleura, mediastinum } \\
\text { cancer of the digestive system }
\end{gathered}
$$

(cancer of the esophagus, esophageal-gastric junction, stomach, small intestine, large intestine, pancreas, Vater's wart, gallbladder, bile ducts, liver cancer)

$$
\text { breast cancer }
$$

cancer of the female reproductive system

(cancer of the vulva, vagina, cervix, endometrium, uterine sarcomas, malignant tumors of the ovary, pregnancy trophoblastic disease)

cancer of the genitourinary system (cancer of the testes, prostate, bladder, kidney, penile cancer)

cancer of the endocrine system

(thyroid neoplasms, neuroendocrine neoplasms of the gastrointestinal tract, lungs, adrenal gland neoplasms, parathyroid neoplasms, pituitary adenomas)

\begin{tabular}{ccc}
\hline melanoma & 28 & 5 \\
\hline osteosarcoma & 24 & 4 \\
\hline soft tissue sarcoma & 21 & 4 \\
\hline skin cancer & 0 & 82 \\
\hline a hematological tumor (lymphomas, leukemias, etc.) & 15 \\
\hline
\end{tabular}

\section{Number Percentage [\%]}

\begin{tabular}{ll}
21 & 4 \\
\hline 104 & 19 \\
\hline 74 & 14 \\
\hline
\end{tabular}

57

55

10

48

9

16

3

14

3
The question did not apply to 239 people (44\%). Among patients undergoing systemic treatment $(\mathrm{n}=305$, $56.06 \%)$ in $63 \%(n=191)$ of respondents, the pandemic 
Table 3. Relationships between responses to the questions included in the proprietary survey concerning the type of cancer, place of residence and treatment, education, age and situation of the patient, difficulties encountered by patients, visit shifts, application of preventive measures, and anxiety related to visits in the health care center during the COVID-19 pandemic.

\begin{tabular}{|c|c|c|}
\hline \multicolumn{3}{|c|}{ Statistically significant correlations } \\
\hline Variable 1 & Variable 2 & P-value \\
\hline the type of cancer & $\begin{array}{l}\text { postponing a scheduled imaging examination } \\
\qquad(\mathrm{CT}, \mathrm{USG}, \mathrm{MRI}, \mathrm{PET})\end{array}$ & $p=0.0366$ \\
\hline $\begin{array}{l}\text { difficulty in reaching the medical facility where treatment or } \\
\text { follow-up after oncological treatment takes place }\end{array}$ & place of residence & $p=0.0339$ \\
\hline postponing a scheduled radiotherapy & $\begin{array}{l}\text { rescheduling a scheduled visit to a specialist, } \\
\text { clinical oncologist, or radiotherapist }\end{array}$ & $p=0.0000$ \\
\hline postponing a scheduled radiotherapy & $\begin{array}{l}\text { postponing a scheduled imaging examination } \\
\qquad(\mathrm{CT}, \mathrm{USG}, \mathrm{MRI}, \mathrm{PET})\end{array}$ & $p=0.0429$ \\
\hline postponing a scheduled systemic treatment & postponing a scheduled radiotherapy & $p=0.0000$ \\
\hline postponing a scheduled systemic treatment & $\begin{array}{l}\text { rescheduling a scheduled visit to a specialist, } \\
\text { clinical oncologist, or radiotherapist }\end{array}$ & $p=0.0000$ \\
\hline postponing a scheduled systemic treatment & $\begin{array}{l}\text { postponing a scheduled imaging examination } \\
\qquad(C T, \text { USG, MRI, PET) }\end{array}$ & $p=0.0000$ \\
\hline $\begin{array}{l}\text { rescheduling a scheduled visit to a specialist, clinical oncologist, } \\
\text { or radiotherapist }\end{array}$ & $\begin{array}{l}\text { postponing a scheduled imaging examination } \\
\text { (CT, USG, MRI, PET) }\end{array}$ & $p=0.0000$ \\
\hline $\begin{array}{l}\text { rescheduling a scheduled visit to a specialist, clinical oncologist, } \\
\text { or radiotherapist }\end{array}$ & $\begin{array}{l}\text { the patient's situation (during treatment or } \\
\text { follow-up after oncological treatment) }\end{array}$ & $p=0.0112$ \\
\hline $\begin{array}{l}\text { rescheduling a scheduled visit to a specialist, clinical oncologist, } \\
\text { or radiotherapist }\end{array}$ & $\begin{array}{l}\text { voivodeship where the patient's treatment/control } \\
\text { takes place }\end{array}$ & $p=0.0193$ \\
\hline feeling anxious about visiting a medical facility & $\begin{array}{l}\text { the patient's situation (during treatment or } \\
\text { follow-up after oncological treatment) }\end{array}$ & $p=0.0042$ \\
\hline $\begin{array}{l}\text { use of preventive measures (covering the mouth and nose, } \\
\text { washing hands regularly, and keeping social distance) }\end{array}$ & age & $p=0.0401$ \\
\hline \multicolumn{3}{|c|}{ Statistically non-significant correlations } \\
\hline Variable 1 & Variable 2 & P-value \\
\hline the type of cancer & $\begin{array}{l}\text { rescheduling the planned systemic treatment } \\
\text { (chemotherapy/biological treatment/hormone therapy) }\end{array}$ & $p=0.0862$ \\
\hline the type of cancer & postponing a scheduled radiotherapy & $p=0.8484$ \\
\hline the type of cancer & $\begin{array}{l}\text { rescheduling a scheduled visit to a specialist, } \\
\text { clinical oncologist, or radiotherapist }\end{array}$ & $p=0.4010$ \\
\hline the type of cancer & feeling anxious about visiting a medical facility & $p=0.0747$ \\
\hline the type of cancer & use of preventive measures & $p=0.05197$ \\
\hline postponing a scheduled radiotherapy & $\begin{array}{l}\text { voivodeship where the patient's treatment/control } \\
\text { takes place }\end{array}$ & $p=0.0624$ \\
\hline postponing a scheduled systemic treatment & $\begin{array}{l}\text { the patient's situation (during treatment or } \\
\text { follow-up after oncological treatment) }\end{array}$ & $p=0.1301$ \\
\hline $\begin{array}{l}\text { postponing a scheduled imaging examination } \\
\qquad(C T, \text { USG, MRI, PET) }\end{array}$ & $\begin{array}{l}\text { the patient's situation (during treatment or } \\
\text { follow-up after oncological treatment) }\end{array}$ & $p=0.2069$ \\
\hline $\begin{array}{l}\text { postponing a scheduled imaging examination } \\
\qquad(C T, \text { USG, MRI, PET) }\end{array}$ & $\begin{array}{l}\text { voivodeship where the patient's treatment/control } \\
\text { takes place }\end{array}$ & $p=0.0656$ \\
\hline $\begin{array}{l}\text { use of preventive measures (covering the mouth and nose, } \\
\text { washing hands regularly, and keeping social distance) }\end{array}$ & $\begin{array}{l}\text { the patient's situation (during treatment or } \\
\text { follow-up after oncological treatment) }\end{array}$ & $p=0.06897$ \\
\hline $\begin{array}{l}\text { use of preventive measures (covering the mouth and nose, } \\
\text { washing hands regularly, and keeping social distance) }\end{array}$ & $\begin{array}{l}\text { voivodeship where the patient's treatment/control } \\
\text { takes place }\end{array}$ & $p=0.1404$ \\
\hline $\begin{array}{l}\text { use of preventive measures (covering the mouth and nose, } \\
\text { washing hands regularly and keeping social distance) }\end{array}$ & the place of residence & $p=0.4884$ \\
\hline $\begin{array}{l}\text { use of preventive measures (covering the mouth and nose, } \\
\text { washing hands regularly, and keeping social distance) }\end{array}$ & education & $p=0.6567$ \\
\hline $\begin{array}{l}\text { use of preventive measures (covering the mouth and nose, } \\
\text { washing hands regularly and keeping social distance) }\end{array}$ & $\operatorname{sex}$ & $p=0.6382$ \\
\hline postponing a scheduled systemic treatment & $\begin{array}{l}\text { voivodeship where the patient's treatment/control } \\
\text { takes place }\end{array}$ & $p=0.0807$ \\
\hline
\end{tabular}


did not affect the timing of the planned therapy. However, this date was postponed in $37 \%$ of respondents $(\mathrm{n}=114)$.

Two hundred sixty-seven people (49\%) reported that the coronavirus delayed scheduled visits to a specialist clinical oncologist/radiotherapist. The rest of the respondents, i.e., 277 (51\%), did not experience such a problem.

Seventy-two respondents (13.2\%) were not asked whether the COVID-19 pandemic had an impact on the timing of planned imaging examinations, such as computed tomography (CT), ultrasound, magnetic resonance imaging (MRI), or positron emission tomography (PET). Among people undergoing imaging studies at that time $(\mathrm{n}=472,86.8 \%)$, as many as $41.7 \%(\mathrm{n}=197)$ said that the date of planned studies was postponed, as opposed to $58.3 \%(\mathrm{n}=275)$ of respondents who had said that such a situation did not take place.

The survey asked about the increased level of anxiety associated with visits to a medical facility during a pandemic. Three hundred eighty-five patients (71\%) answered affirmatively, 138 negatively (25\%), and 21 - "I do not know" (4\%).

As many as 489 respondents (89.9\%) declared that they used preventive measures: covering the mouth and nose, washing hands regularly, and maintaining social distance. Thirty-five respondents (6.4\%) used only some of the listed ones, and 13 indicated the answer "sometimes" (2.4\%). Only seven respondents (1.3\%) did not follow the sanitary and epidemiological recommendations.

The group of respondents was statistically analyzed for the correlation between:

- the type of cancer and the postponement of the scheduled radiotherapy, systemic treatment, visits to a specialist, clinical oncologist/radiotherapist, the level of anxiety associated with visits to a medical facility, and the use of preventive measures (e.g., covering the mouth and nose);

- difficulty in reaching the medical facility and the place of residence;

- postponing the scheduled radiotherapy and postponing the planned visit to the doctor, imaging studies, and the voivodeship;

- postponing the scheduled systemic treatment and postponing the scheduled radiotherapy, visits to a specialist, clinical oncologist/radiotherapist, imaging studies, the voivodeship, and the patient's situation (during treatment/follow-up after oncological treatment);

- postponing the scheduled visit to a specialist clinical oncologist/radiotherapist and postponing the scheduled imaging examinations, the region and the patient's situation (during treatment/during follow-up after oncological treatment);

- rescheduling the scheduled imaging studies and the voivodeship and situation of the patient (during treatment/during follow-up after oncological treatment);

- the level of perceived anxiety related to visits to a medical facility and the patient's situation (during treatment/ during follow-up after oncological treatment);

- the use of preventive measures and the gender, age, voivodeship, place of residence, education, and situation of the patient (during treatment/during follow-up after oncological treatment).

The statistical correlations are characterized in Table 3 with the division into statistically significant and non-significant.

\section{DISCUSSION}

Scientists reported that the increased rate of disease progression, pain, and excessive mortality often result from disruptions in healthcare caused by natural disasters, including the current epidemiological situation [15-17]. The COVID-19 pandemic has significantly impeded oncological treatment, nullifying attempts to treat cancer patients adequately [18].

The results of the conducted survey were confronted with reports from scientific research. As many as 35\% of respondents indicated that the scheduled radiotherapy was changed. The situation was similar in the case of systemic treatment $-37 \%$ of respondents said that the date of the visit was postponed. Treatment delay might be a safe procedure in the treatment of some neoplasms [19]. However, according to reports, postponing the initiation of therapy in most oncological diseases was associated with worse overall survival [20]. This report was confirmed by Nagar and Formenti, who indicated that in women with locally advanced cervical cancer, delaying the use of radiotherapy reduced overall survival [21]. $10 \%$ of respondents confirmed that they had breast cancer. Scientists reported that in this group of patients delaying the initiation of adjuvant radiotherapy by more than eight weeks after surgery increased the risk of local recurrence twice [22]. The authors of another study emphasized that treatment should be started quickly in people with late-stage breast cancer. In an analysis by McLaughlin et al., delaying the treatment of women with advanced breast cancer by 60 days or more was associated with an $85 \%$ increase in the risk of death due to oncological disease and an increase in overall mortality by $65 \%$ [23]. However, Darby et al. showed that radiotherapy reduced the risk of local recurrence. The authors also observed a $3.8 \%$ absolute reduction in the risk of death from breast cancer in the 15-year follow-up [24]. The effect of postponing radiotherapy longer than 20 weeks impaired local control of breast cancer and worsened survival due $[25,26]$.

The situation for other cancers is similar to the delay in the treatment of breast cancer. In one of the studies, seven neoplasms (breast, bladder, rectal, colon, cervical, lung, and head and neck cancer) were analyzed. They accounted for $44 \%$ of all cases in terms of surgical, systemic treatment, and radiotherapy. All three treatments were shown to increase the risk of death if delayed for four weeks. In the surgical context, each 4-week treatment delay was associated with a $6-8 \%$ increase in the risk of death. The authors noticed an even more pronounced influence of timely treatment in relation to radiotherapy and systemic therapy - the risk of death due to the postponement of radical radiotherapy for head and neck cancer increased by $9 \%$, and in the case of delay in the adjuvant systemic 
treatment of colorectal cancer - by 13\%. Treatment delays of 8 to 12 weeks are also associated with a higher risk of death. Due to an 8 -week delay in surgery for breast cancer, the risk of death increases by $17 \%$, and due to a 12 -week delay in surgery - by $26 \%$. According to the researchers, delays shorter than four weeks should also not be considered safe, indicating that a two-week postponement of surgery for breast cancer is associated with an increase in death by $4 \%$ [27].

Maringe et al. conducted a study based on several different cancer survival scenarios. They analyzed the impact of diagnostic delays lasting 12 months (March 16, 2020, to March 15, 2021) caused by the pandemic in the UK. Four types of cancer were selected for scientific observation, and the data of 32,583 patients with breast cancer, 24,975 with colorectal cancer, 6,744 with esophageal cancer, and 29,305 with lung cancer were analyzed. In all scenarios, the researchers estimated the absolute reduction in survival. They determined that due to delays in diagnosis, by comparing the results with data from the pre-pandemic period, the additional number of deaths related to the above-mentioned cancers over the next five years would range from 3,291 to 3,621 deaths [28].

One should also pay attention to the reports of the scientific world on gliomas, as well as head and neck cancer. In high-grade gliomas, the risk of death increases by $8.9 \%$ for each week of postponement of radiotherapy beyond two weeks after surgery [29]. However, as reported by Katsigiannis et al., in patients with newly diagnosed glioblastoma, delaying the initiation of radiotherapy by more than 48 days after surgery reduced survival by about seven months [30]. Another study, which included a group of 234,861 people with head and neck cancer, showed that prolonging the time between surgery and postoperative radiotherapy also reduced overall survival [31].

On the other hand, some authors draw attention to possible and less risky shifts in the treatment of patients depending on the type and stage of cancer. Regarding mortality, an analysis by Hartman et al. showed that treatment of stage II prostate cancer delayed up to 6 months was not harmful to patients. However, authors observed that in patients with stage I, II, and III head and neck cancer, delayed treatment was associated with a significant deterioration in survival [32]. Wallis et al., based on a literature review, reported that priority treatment should be given to patients with advanced bladder cancer, advanced cancer of the kidneys, testes, and penis. On the other hand, treatment of patients with medium and high-risk prostate cancer may be postponed by 3-6 months without changing the results, and the use of active surveillance in the case of low-risk patients might be appropriate. The safe postponement also applies to T1/T2 kidney cancer. The same cannot be said for locally advanced kidney tumors $(\geq \mathrm{T} 3)$, where rapid treatment is required. The authors also mentioned that a delay of $\geq$ 3 months in inguinal lymphadenectomy in penile cancer translated into unfavorable results. In patients with highstage cancer of the upper urinary tract, a delay of 12 weeks in nephroureterectomy was not associated with worse survival [33]. The authors of the article "Urologic oncology practice during COVID-19 pandemic: A systematic review on what can be deferrable vs. nondeferrable" reached similar conclusions. Based on a literature review, the authors found that most urological oncology operations that were delayed did not affect mortality and long-term outcomes. Katims et al. pointed out that testicular and penile cancer, kidney cancer (T3 kidney tumors), muscle-infiltrating bladder cancer, and high-grade epithelial cancer should not be underestimated in this regard. Chemotherapy is the initial solution in the case of muscle-infiltrating bladder and testicular cancer [34].

It is also worth referring to another type of cancer patients suffering from cancer of the paranasal sinuses and anterior cranial fossa are at significant risk because their tumor is in close contact with critical neurovascular structures - the brain, meninges, optic nerve, and carotid artery. Turri-Zanoni et al. stated that delays in diagnosis must not be allowed in patients with cancer of the paranasal sinuses and anterior fossa of the skull, even in the event of a sudden infectious threat. A PET-CT scan of the body and contrast-enhanced radiographs of the head and neck (CT and MRI) must be performed to assess the cancer stage accurately. However, the authors of this study pointed out that postponement of treatment was indicated in patients with high-risk comorbidities. Treatment, such as radiochemotherapy, immunotherapy, or surgery, might significantly affect the body's immune function. And this, in turn, might increase the risk of death from SARS-CoV-2 virus infection [35].

Many scientific papers deal with radiotherapy in the current epidemiological situation. Researchers agree that radiation therapy can be carried out safely during the COVID-19 pandemic, avoiding possibly harmful delays in cancer treatment. Researchers point out that suboptimal radiation therapy, with interruptions or delays, can be a threat to survival and local control. Importantly, in some situations, radiation therapy can safely replace surgery. This is the case with bladder, prostate, esophagus, pancreatic, head, and neck cancer, as well as non-small cell lung cancer [21]. It is worth noting that most regimens induce immunosuppression only to a moderate degree [36]. Patients undergoing radiotherapy do not occupy intensive care unit beds or ventilators needed by COVID-19 patients. Thanks to converting standard regimens into hypofractionated radiotherapy, it is possible to limit visits to the treatment facility. Hence, this procedure should be available to patients and remain an essential therapeutic method [21].

Surgery is undoubtedly an important treatment method for certain types of cancer. The analysis involved 34 asymptomatic patients who underwent various elective surgery during the SARS-CoV-2 virus incubation period. All subjects developed pneumonia caused by the coronavirus after surgery. Almost half (44\%) required intensive care unit care, and half of these patients died [37]. Also, Allegra et al. reported that the possibility of immunosuppression, critical complications from the respiratory system, or death should be considered when choosing to continue oncological 
treatment, including surgery. However, they emphasized that the risk of progression might increase due to the delay in oncological surgery procedures. The authors of this study stressed that some types of cancer require urgent treatment, including lung cancer, pancreatic cancer, and some hematological diseases (e.g., acute leukemia). However, in their opinion, it was permissible to treat other types of cancer at an early stage with some delay, such as cervical, prostate, and breast cancer, as well as non-melanoma skin cancers [1]. They also noted that treating cancer within the 14 days from COVID-19 diagnosis was considered a highly dangerous risk factor for events such as acute respiratory distress syndrome (28.6\%), septic shock (3.6\%), and acute myocardial infarction (3.6\%). It is worth noting that among patients participating in the study, $28.6 \%$ developed COVID-19 infection during hospitalization [38].

Almost half of the survey respondents (49\%) experienced a delay in visiting a specialist, clinical oncologist, or radiotherapist. $51.7 \%$ of them were under treatment, and $48.3 \%$ were in control after oncological treatment. $41.7 \%$ of people, including $53.8 \%$ during and $46.2 \%$ after cancer treatment, experienced postponement of imaging studies. Although these results may seem disturbing, their interpretation should be individual and depend on the type of cancer, the stage of treatment or the time since the end of therapy, and most importantly - the scale of these visit shifts. Delaying controls for too long can have negative consequences for the patient.

In the study "Masks - protection or a threat? The analysis of social attitudes towards the order to cover the mouth and nose during the COVID-19 pandemic" 2,512 Poles were asked about compliance with the introduced recommendations. $76.1 \%$ of respondents replied that they always complied with the recommendations [39]. It seems that Poles with oncological diseases complied with the recommendations to a greater extent. As many as $89.9 \%$ of respondents stated that they adhered to indications related to the SARS-CoV-2 virus pandemic, using preventive measures, such as covering the mouth and nose, regular washing hands, and maintaining social distance. This probably indicated a higher awareness of cancer patients in the field of prevention. In other words, this may suggest that cancer patients are aware of the seriousness of the threat posed by the SARS-CoV-2 virus, especially for people with comorbidities.

During the COVID-19 pandemic, a relationship was noticed between the place of residence and the difficulty in reaching a medical facility. This problem occurred in almost half of the respondents (48\%). In addition, most of the respondents $(71 \%)$ experienced more significant anxiety related to visits to a medical facility. Scientists indicated the hospital environment as the source of the SARS-CoV-2 virus spread, citing the report, where infection acquired in one of the institutions (Zhongnan Hospital of Wuhan University) concerned $41.3 \%$ of patients staying in hospital [40]. Cancer patients may be exposed to SARS-CoV-2 infection, as post-treatment monitoring or cancer therapy were associated with hospital visits [41].
Finally, it is essential to note the statistics that show that of the 335 patients who died from COVID-19 in Italy, 20\% had active cancer disease [42]. Some patients were simply more likely to become ill and, consequently, died. The authors determined that the patient's situation (state during treatment or follow-up after treatment) significantly influenced the perceived anxiety associated with visits in a medical facility $(\mathrm{p}=0.0042)$. Patients with hematological neoplasms may be more susceptible to infections due to cytotoxic therapies used in these diseases, reducing lymphocyte subsets [43, 44]. Radiotherapy may also increase myelosuppression and increase the risk of SARS-CoV-2 infection [45]. Saini et al. emphasize that stem cell transplant recipients and patients with hematological and other cancers may be particularly exposed to the risk of coronavirus. Immunosuppression related to treatment or disease might not be the only reason, but also age and comorbidities [7]. There are other examples of people who are likely to be at greater risk of COVID-19, e.g., patients receiving cytotoxic chemotherapy, radical radiation therapy for lung cancer, antibodies, immunotherapy, PARP inhibitors or protein kinase inhibitors, and patients with lymphoma, leukemia, or myeloma and those who have recently received bone marrow or stem cell transplants [46].

It is worth mentioning that the scope of readiness and capabilities of the healthcare system, as well as organizational structures and the efficiency in responding to disorders in cancer treatment, vary considerably $[47,48]$.

\section{CONCLUSIONS}

Our results indicate possible threats - an increase in the percentage of patients in the advanced stage of the disease or increased mortality. The authors suggest implementing example solutions:

- ensuring continuity of treatment in cancer centers,

- not including oncological entities in the healthcare system for patients suffering from COVID-19,

- popularizing and promoting vaccinations to prevent COVID-19 in a group of people with neoplastic diseases. This would reduce the likelihood of postponing hospitalization and cancer treatment due to SARS-CoV-2 infection,

- ensuring uninterrupted, easy access to preventive programs that increase the chance of early detection and more effective treatment of cancer,

- maintaining special oncological vigilance among medical staff due to the limited personal contact with the patient due to the ongoing pandemic.

It is worth noting that the potential risk of SARS-CoV-2 infection must be individually balanced with the delay in cancer treatment in each patient.

\section{REFERENCES}

1. Allegra A, Pioggia G, Tonacci A, et al. Cancer and SARS-CoV-2 infection: Diagnostic and therapeutic challenges. Cancers. 2020;12:1581. doi: 10.3390/cancers 12061581

2. van Dam PA, Huizing M, Mestach G, et al. SARS-CoV-2 and cancer: are they really partners in crime? Cancer Treat Rev. 2020;89:102068. https:// doi.org/10.1016/j.ctrv... 
3. Derosa L, Melenotte C, Griscelli F, et al. The immuno-oncological challenge of COVID-19. Nat Cancer 2020; 1, 946-964. https://doi. org $/ 10.1038 / 543018$

4. Liang W, Guan W, Chen R, et al. Cancer patients in SARS-CoV-2 infection: a nationwide analysis in China. Lancet Oncol. 2020;21(3):335-337; doi:10.1371/journal.pone.0213209

5. Cho H, Mariotto AB, Mann BS, et al. Assessing non-cancer-related health status of US cancer patients: other-cause survival and comorbidity prevalence.Am JEpidemiol.2013;178(3):339-349; doi:10.1093/aje/kws580,

6. Richardson S, Hirsch JS, Narasimhan M, et al. The Northwell COVID-19 Research Consortium. Presenting characteristics, comorbidities, and outcomesamong 5700 patients hospitalized with COVID-19 in the New York City area. JAMA. 2020;323(20):2052-2059. doi:10.1001/jama.2020.6775

7. Saini KS, de Las Heras B, de Castro J, et al. Effect of the COVID-19 pandemic on cancer treatment and research. Lancet Haematol. 2020 Jun;7(6):e432-e435. doi: 10.1016/S2352-3026(20)30123.

8. Jazieh A.R., Alenazi T.H., Alhejazi A, et al. Outcome of oncology patients infected with coronavirus. JCO Glob. Oncol. 2020;6:471-475. doi: 10.1200/G0.20.00064.

9. Chowell G, Ayala A, Berisha V, et al. Risk factors for mortality among 2009 A/H1N1 Influenza Hospitalizations in Maricopa County, Arizona, April 2009 to March 2010. Comput. Math. Methods Med. 2012;2012:1-8; doi: 10.1155/2012/914196

10. Zalecenia Polskiego Towarzystwa Onkologicznego i Polskiego Towarzystwa Chirurgii Onkologicznej w sprawie postępowania z pacjentami onkologicznymi z dnia 18.03.2020 r (online) $2020 \mathrm{Mar}$ [download: 1.12.2020]; https://pto.med.pl/zalecenia-p...

11. Zalecenia i rekomendacje PTO dla pacjentów onkologicznych i placówek onkologicznych w związku z epidemią wirusa SARS-Cov-2 - aktualizacja z dnia 08.04.2020 r. (online) 2020 Apr [download: 10.12.2020]; https:// pto.med.pl/zalecenia-i...

12. Wysocki PJ, KwintaŁ, Paweł Potocki et al. Leczenie systemowe pacjentów z rozpoznaniem choroby nowotworowej w kontekście pandemii SARSCoV-2 — stanowisko Polskiego Towarzystwa Onkologii Klinicznej (online) [download: 12.12.2020];https://pto.med.pl/sites/defau

13. Rekomendacje Konsultanta Krajowego dla Radioterapii w Warunkach Epidemii COVID-19 (online) $2020 \mathrm{Mar}$ [download 18.12.2020]; https:// pto.med.pl/sites/defau...

14. Wysocki W, Kładny J, Murawa D et al. Stanowisko Polskiego Towarzystwa Chirurgii Onkologicznej w sprawie postępowania u chorych na nowotwory wymagających leczenia chirurgicznego w okresie zagrożenia epidemiologicznego (online) 2020 Mar [download 28.11.2020]; https:// www.mp.pl/chirurgia/wy...,stanowisko-ptcho-w-sprawie-leczeniachirurgicznego-chorych-na-nowotwory-wobec-covid-19

15. Dhillon N, Castillo D'Andreis E, Boulmay BC. Hepatocellular carcinoma (HCC) outcomes in a public hospital setting: characteristics and outcomes from the interim LSU public hospital (ILH) in New Orleans. Am Soc Clin Oncol 2015;33(15):e17533

16. McKinney N, Houser C, Meyer-Arendt K. Direct and indirect mortality in Florida during the 2004 hurricane season. Int J Biometeorol 2011;55(4):533-546

17. Man RX-G, Lack DA, Wyatt CE, Murray V. The effect of natural disasters on cancer care: a systematic review. Lancet Oncol 2018;19(9):e482-e499

18. Blandino G. Cancer at the time of the COVID-19 hurricane. J Exp Clin Cancer Res. 2020;39:74; doi: 10.1186/s13046-020-01575-1.

19. Van den Bergh $\mathrm{RCN}$, Albertsen $\mathrm{PC}$, Bangma $\mathrm{CH}$, et al. Timing of curative treatment for prostate cancer: a systematic review. Eur Urol. 2013;64(2):204-215; doi:10.1016/j.eururo.2013.02.024
20. Khorana AA, Tullio K, Elson P, et al. Time to initial cancer treatment in the United States and association with survival over time: an observational study. PLoS One. 2019;14(3):e0213209; doi:10.1371/journal.pone.0213209

21. Nagar H, Formenti SC. Cancer and COVID-19 — potentially deleterious effects of delaying radiotherapy. Nat Rev Clin Oncol 2020;17:332334; https://doi.org/10.1038/s41571...

22. Huang J, Barbera L, Brouwers $M$, et al. Does delay in starting treatment affect the outcomes of radiotherapy? A systematic review. J Clin Oncol. 2003;21:555-563.

23. McLaughlin JM, Anderson RT, Ferketich AK, et al. Effect on Survival of Longer Intervals Between Confirmed Diagnosis and Treatment Initiation Among Low-Income Women With Breast Cancer. J Clin Oncol. 2012;30(36):4493-4500

24. Darby S, McGale P, Correa C, et al. Effect of radiotherapy after breastconserving surgery on 10-year recurrence and 15 -year breast cancer death: meta-analysis of individual patient data for 10,801 women in 17 randomised trials. Lancet 2011;12;378(9804):1707-16; doi: 10.1016/ S0140-6736(11)61629-2.

25. Gupta S, King WD, Korzeniowski M, et al. The Effect of Waiting Times for Postoperative Radiotherapy on Outcomes for Women Receiving Partial Mastectomy for Breast Cancer: a Systematic Review and Meta-Analysis. Clin Oncol 2016; 28:739-49; doi:10.1016/j.clon.2016.07.010

26. Olivotto IA, Lesperance ML, Truong PT, et al. Intervals longer than 20 weeks from breast-conserving surgery to radiation therapy are associated with inferior outcome for women with early-stage breast cancer who are not receiving chemotherapy. J Clin Oncol 2009; 27:16-23. doi:10.1200/JC0.2008.18.1891

27. Hanna TP, King WD, Thibodeau S, et al. Mortality due to cancer treatment delay: systematic review and meta-analysis. BMJ 2020;371:m4087; doi: 10.1136/bmj.m4087

28. Maringe C, Spicer J, Morris M, et al. The impact of the COVID-19 pandemic on cancer deaths due to delays in diagnosis in England, UK: a national, population-based, modelling study. Lancet Oncol 2020;21 :10231034; https://doi.org/10.1016/S1470-...]

29. Irwin C, Hunn M, Purdie G, et al. Delay in radiotherapy shortens survival in patients with high grade glioma. J. Neurooncol 2007;85:339-343; doi: $10.1007 / s 11060-007-9426-z$

30. Katsigiannis S, Krischek B, Barleanu S, et al. Impact of time to initiation of radiotherapy on survival after resection of newly diagnosed glioblastoma. Radiat. Oncol. 2019;14:73

31. Harris JP, Chen MM, Orosco RK, et al. Association of survival with shorter time to radiation therapy after surgery for US patients with head and neck cancer. JAMA Otolaryngol. Head Neck Surg. 2018;144:349-359

32. Hartman HE, Sun Y, Devasia TP, et al. Integrated Survival Estimates for Cancer Treatment Delay Among Adults With Cancer During the COVID-19 Pandemic. JAMA Oncol. 2020;6(12):1881-1889. doi:10.1001/ jamaoncol.2020.5403

33. Wallis CJD, Novara G, Marandino L, et al. Risks from deferring treatment for genitourinary cancers: a collaborative review to aid triage and management during the COVID-19 pandemic. Eur Urol. 78 (2020):29-42, 10.1016/j.eururo.2020.04.063

34. Katims AB, RazdanS, EilenderBM. Urologic oncology practiceduring COVID-19 pandemic: a systematic review on what can be deferrable vs. Nondeferrable. Urol Oncol. 2020;38:783-792.https://doi.org/10.1016/j.urol...

35. Turri-Zanoni M, Battaglia P, Karligkiotis A, et al. Managing care for patients with sinonasal and anterior skull base cancers during the COVID-19 pandemic. Head \& Neck. 2020;42:1503-1506; doi: 10.1002/ hed.26257 https://onlinelibrary.wiley.co... 
36. Wild AT, Herman JM, Dholakia AS, et al. Lymphocyte-sparing effect of stereotactic body radiation therapy in patients with unresectable pancreatic cancer. Int J Radiat Oncol Biol Phys. 2016;94:571-579

37. Lei S, Jiang F, Su W, et al. Clinical characteristics and outcomes of patients undergoing surgeries during the incubation period of COVID-19 infection. EClinicalMedicine. 2020:100331; doi: 10.1016/j. eclinm.2020.100331.

38. Al-Quteimat OM, Amer AM. The Impact of the COVID-19 Pandemic on Cancer Patients. Am J Clin Oncol 2020;43:452-455; doi: 10.1097/ COC.0000000000000712.

39. Krzyżak K, Kościelecka K, KućA, et al. Maseczki-ochrona czy zagrożenie? Analiza postaw społecznych wobec nakazu zakrywania ust i nosa w czasie pandemii COVID-19. Wiad Lek. 2020;73(8):1641-1649; doi: 10.36740/WLek202008110

40. Wang D, Hu B, Hu C, et al. Clinical characteristics of 138 hospitalized patients with 2019 novel coronavirus-infected pneumonia in Wuhan, China. JAMA. 2020;323(11):1061-1069; doi:10.1001/jama.2020.1585

41. Yu J, Ouyang W, Chua MLK, et al. SARS-CoV-2 Transmission in Patients With Cancer at a Tertiary Care Hospital in Wuhan, China. JAMA Oncol. 2020;6(7):1108-1110; doi:10.1001/jamaoncol.2020.0980

42. Onder $G$, Rezza G, Brusaferro $S$. Case-fatality rate and characteristics of patients dying in relation to COVID-19 in Italy. JAMA. 2020; 323(18):1775-1776; doi: 10.1001/jama.2020.4683.

43. UK Coronavirus Cancer Monitoring Project Team. The UK Coronavirus cancer monitoring project: Protecting patients with cancer in the era of COVID-19. Lancet Oncol. 2020;21:622-624; doi: 10.1016/S14702045(20)30230-8.

44. Kutikov A, Weinberg DS, Edelman MJ, et al. A war on two fronts: Cancer care in the time of COVID-19. Ann. Intern. Med. 2020:M20-1133. doi: 10.7326/M20-1133.

45. Zhao Z, Yang C, Li C. Strategies for patient with cancer during COVID-19 pandemic. Asia Pac. J. Clin. Oncol. 2020 doi: 10.1111/ajco.13363.

46. National Health Service England Clinical guide for the management of noncoronavirus patients requiring acute treatment: cancer (online) 2020 Mar [download 2.12.2020];https://www.england.nhs.uk/cor...

47. Richards $M$, Anderson M, Carter $P$, et al. The impact of the COVID-19 pandemic on cancer care. Nat Cancer 2020;1(6):565-567. https://doi. org/10.1038/s43018...

48. Printz $C$. When a global pandemic complicates cancer care. Cancer 2020;126(14):3171-3173. https://doi.org/10.1002/cncr.3...

\section{ORCID and contributionship:}

Klaudia Ewa Kościelecka - 0000-0002-6694-8182 ${ }^{A-F}$

Aleksandra Joanna Kuć - 0000-0002-3634-1347 A-F

Daria Małgorzata Kubik - 0000-0002-3588-5764 ${ }^{A-F}$

Tomasz Męcik-Kronenberg - 0000-0002-0618-8265 E-F

Dariusz Ceglarz - 0000-0001-6660-9327 C-F

\section{Acknowledgment:}

The authors state that the study was not sponsored in any way and that there is no conflict of interest. The survey was conducted based on sociological research, and the information collected in it did not directly impact the method and place of treatment. Therefore, no application for consent to conduct the study was submitted to the Bioethics Committee.

\section{Conflict of interest:}

The Authors declare no conflict of interest.

\section{CORRESPONDING AUTHOR Klaudia Ewa Kościelecka}

Student Research Group at the Chair and Department of Pathomorphology, Faculty of Medical Sciences

in Zabrze Medical Univeristy of Silesia ul. 3-go Maja 13, 41-880, Zabrze, Poland e-mail:klaudia.koscielecka@gmail.com

Received: 22.03 .2021

Accepted: 05.05 .2021

A - Work concept and design, B - Data collection and analysis, C - Responsibility for statistical analysis, D-Writing the article, $\mathbf{E}$-Critical review, $\mathbf{F}$ - Final approval of the article 